\title{
Cultural Capital and the Liberal Political Attitudes of Professionals: Comment on Brint
}

\section{Citation}

Lamont, Michèle. 1987. Cultural capital and the liberal political attitudes of professionals:

Comment on Brint. American Journal of Sociology 92(6): 1501-1506.

\section{Published Version}

http://dx.doi.org/10.1086/228673

\section{Permanent link}

http://nrs.harvard.edu/urn-3:HUL.InstRepos:3428542

\section{Terms of Use}

This article was downloaded from Harvard University's DASH repository, and is made available under the terms and conditions applicable to Other Posted Material, as set forth at http:// nrs.harvard.edu/urn-3:HUL.InstRepos:dash.current.terms-of-use\#LAA

\section{Share Your Story}

The Harvard community has made this article openly available.

Please share how this access benefits you. Submit a story.

\section{Accessibility}




\section{Commentary and Debate}

To conserve space for the publication of original contributions to scholarship, the comments in this section must be limited to brief critiques. They are expected to address specific errors or flaws in articles and reviews published in the $A J S$. Comments on articles are not to exceed 1,500 words, those on reviews 750 words. Longer or less narrowly focused critiques should be submitted as articles. Authors of articles and reviews are invited to reply to comments, keeping their replies to the length of the specific comment. The $A J S$ does not publish commenters' rebuttals to authors' replies. We reserve the right to reject inappropriate or excessively minor comments.

\section{CULTURAL CAPITAL AND THE LIBERAL POLITICAL ATTITUDES OF PROFESSIONALS: COMMENT ON BRINT}

In his article, "'New Class' and Cumulative Trend Explanations of the Liberal Political Attitudes of Professionals" (AJS 90 [July 1984]: 30-71), Steven Brint analyzes the social bases of liberal political attitudes in the new class, focusing on the differences among various occupational aggregates. He criticizes the new-class hypothesis that a class of knowledge workers fundamentally opposed to the business class has recently developed (e.g., Ehrenreich and Ehrenreich 1977; Gouldner 1979; Kristol 1972; Ladd 1978). Brint contends that "the only aggregation [of the new class] to show a consistent, strong pattern of liberalism . . . is clearly not a class but an occupationally based segment of a broader class grouping [i.e., cultural and social specialists]" (p. 37) and that political attitudes among knowledge workers are more reformist than antibusiness. He concludes that liberalism among professionals and managers (1) has little to do with class antagonism and (2) is better explained as "the result of several general trends in American society," such as the coming of age of a notably liberal cohort and the growth of higher education.

Brint's article is an important contribution because it systematically examines the political attitudes of the new class empirically. However, it can be criticized both theoretically and methodologically. First, I argue that, in his attempt to refute the new-class thesis, Brint overlooks impor-

Permission to reprint a comment printed in this section may be obtained only from the author. 
tant similarities in political attitudes among occupational groups that suggest that liberal political attitudes in the new class vary with the dependence of respondents' jobs on private profit making and with the utility of their professional knowledge (or cultural capital) for profit maximization. ${ }^{1} I$ argue that this hypothesis is supported by Brint's data, and I assess his objections to the new-class theory. Second, I criticize Brint's article for using indicators of liberalism that are not relevant for the analysis of the political attitudes of the new class toward the business class. These indicators pertain to moral issues and broader political issues, and they show a weaker relationship between political liberalism and the relative independence from profit maximization than do other attitudinal indicators.

\section{SIMILARITIES OF POLITICAL ATTITUDES AMONG THE NEW-CLASS OCCUPATIONAL GROUPS}

Brint tests the new-class hypothesis with bivariate and multivariate analyses of the political attitudes of various occupational aggregates of the new class using data from the General Social Survey (National Opinion Research Center [NORC] 1974-80). His bivariate analysis shows that the only aggregate of the new class with a consistent and strong pattern of liberalism is Kristol's (1972) new class, which includes professionals in the arts, media, teaching, academic research, and government regulatory and welfare activities. These are the most liberal groups on seven of the 10 attitudinal indicators of political liberalism and personal values Brint uses. The multivariate analysis supports this finding: the most liberal group is the "social and cultural specialists," which includes academics, nonacademic social scientists, arts and culture professionals, architects, the clergy, and traditional professionals (lawyers and doctors). The multivariate analysis also shows membership in the younger cohort and employment in the "enlarged public sector" (see Miller 1975) as the next two strongest predictors of political liberalism.

The group with the most liberal attitudes, after the social and cultural specialists, is young, highly educated human-service specialists, which includes the lower-status "helping professions"-teachers, social workers, librarians, and nurses (see Brint, table 7). The third most liberal group is young, highly educated professionals and managers in the public sector. The least liberal subgroups are the older managers and the older, highly educated technical professionals in the private sector, which in-

1 "Cultural capital" is defined as socially valued material and nonmaterial cultural goods, including education, technical expertise, and high-status culture, that are used as bases of power (see Bourdieu 1979; Lamont and Lareau 1986). 


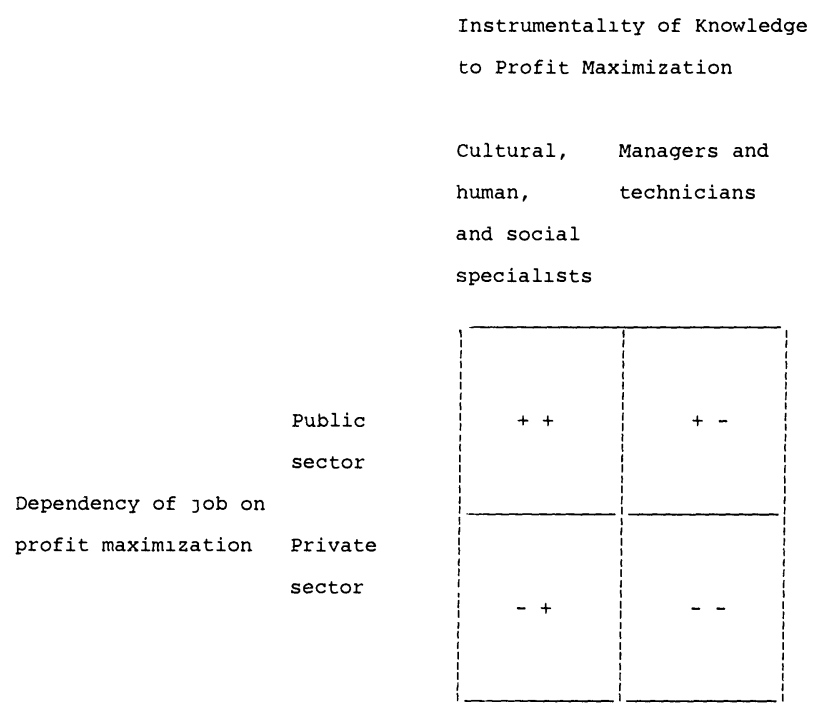

FIG. 1.-Variations in political liberalism

clude business economic specialists, engineers, college-graduate technicians, private-sector doctors and lawyers, and nonacademic scientists.

Leaving aside the issue of age, what do these results tell us about political liberalism in the new class? Generally, political liberalism is stronger in groups that are not directly instrumental to profit maximization, that is, in the arts, education, and social and other services. It is also stronger among employees of the public sector whose jobs are not immediately dependent on profit maximization (for similar results, see McAdams 1984). On the basis of these remarks, Brint's data suggest that political liberalism among the new-class occupational categories varies inversely with the dependence of an individual's job on profit maximization and with the instrumentality of his knowledge for profit maximization. The less dependent individuals' jobs are on profit maximization and the less instrumental they are to profit maximization, the more likely individuals are to have liberal political attitudes (fig. 1). ${ }^{2}$ Using this hypothesis, I will discuss Brint's criticisms of the new-class theory.

Brint is correct in arguing that social and cultural specialists are not a

\footnotetext{
${ }^{2}$ The consistent liberalism of younger respondents noted by Brint could be explained partly by their lower dependence on private profit making due to the availability of parental assistance in the case of middle-class and upper-middle-class children. Space limitations prevent discussion of the effects of occupational self-selection and recruitment processes on the political outlook of occupational groups.
} 
class. However, the above hypothesis suggests that liberalism among relatively autonomous cultural capital workers corresponds to common class interests and is a class phenomenon: liberal attitudes are explained by the common class situation of some new class groups, that is, by the similar relationship that their cultural capital has to profit-driven enterprises, the business class, and economic capital in general. The common interests of relatively autonomous cultural capital workers are to maintain and increase their autonomy and to expand the nonprofit realm by encouraging the development of the public sector, promoting policies to increase business taxation, and supporting values and political ideologies that favor noneconomic aspects of social life, such as postmaterialist values, environmentalism, or New Left politics (see Flanagan 1982; Inglehart 1977; Lipset 1981). From Weber's (1968, vol. 1, p. 304) perspective, a common class situation is a class criterion (see also Giddens 1973, p. 78). Then, liberalism among specific new-class groups is a class phenomenon, contrary to what Brint argues (p. 42). The new-class theory should not be rejected but modified, with a focus on the opposition of relatively autonomous cultural capital workers to business-class interests, rather than on the opposition of a broad, shapeless new class whose common interests are loosely defined.

Brint is incorrect in rejecting the new-class thesis because only the social and cultural specialists have consistently strong, liberal political attitudes. Liberal attitudes are unevenly distributed among knowledge workers and concentrated among social and cultural specialists, and this distribution reflects the differentiated relationships that various occupational groups have with economic capital. Brint is right to reject the newclass thesis on the basis that social and cultural specialists are not a class. However, he should have recognized and explained the distribution of liberal attitudes among subgroups, which suggests that liberalism in the new class is indeed a class phenomenon.

\section{THEORETICAL JUSTIFICATION OF THE INDICATORS OF DISSENT AND LIBERALISM}

Brint's composite liberalism variable is based on 10 attitudinal indicators classified into two categories: those pertaining to antibusiness and egalitarian attitudes, on the one hand, and those related to liberal and reformist attitudes, on the other. He uses attitudes toward income distribution and confidence in business leaders as indicators of egalitarianism and antibusiness sentiment. This choice of indicators is based on the traditional concept of left/right opposition, which is not the most relevant theoretical framework for analyzing the relationship of the new class to the business class given the relationship between liberalism and profit 
dependence shown in his table 7 . In order to analyze this relationship by means of political attitudes and personal values, as Brint claims he wants to, it is necessary to focus on attitudes that pertain directly to the relationship between economic and cultural capital and to strengthening the independence of the new class from the business class. To be consistent, Brint should have used the following indicators: (1) favoring increased governmental spending on social programs, which would increase the institutional bases for nonprofit-oriented professional knowledge; (2) emphasizing noneconomic values, expressed in encouraging intellectual values and rewards at work and in child rearing; and (3) showing a lack of confidence in business leaders. The other indicators-racial integration, redistribution of income, and moral and sexual permissiveness-pertain to moral issues or other political issues (e.g., left/right conflicts) and are not especially associated with the specific class situation of the new class. As shown in table 2 of Brint's article, Kristol's new class, which includes social and cultural specialists, ranks consistently higher on the first set of attitudinal measures, which indicates its opposition to the business class. ${ }^{3}$ In contrast, Ehrenreich and Ehrenreich's (1977), Gouldner's (1979), and Ladd's (1978) groupings, which all include managers and technicians, consistently rank lower on the first set of indicators, and their ranking varies on the second set of indicators. ${ }^{4}$

This suggests that the combination of indicators used by Brint blurs the variations in attitudes toward the business class among new-class occupational groupings and indirectly hides a stronger relationship between political liberalism and relative independence from profit maximization. A reformulation of the new-class theory in the direction described above seems to be more appropriate than its rejection, as suggested by Brint's interpretation of the data.

\section{University of Texas at Austin}

\section{Michele LAMONT}

\section{REFERENCES}

Bourdieu, Pierre. 1979. "Les trois états du capital culturel." Actes de la recherche en sciences sociales $30: 3-6$.

\footnotetext{
${ }^{3}$ The indicator "voted for McGovern in the 1972 presidential election" implies moral values as well as support for policies favoring noneconomic social goals.

${ }^{4}$ The new-class theories considered by Brint include the following occupational groupings: (1) Ehrenreich and Ehrenreich-salaried professionals and managers of all educational levels, (2) Ladd - salaried professionals and managers with baccalaureate and higher-level degrees, (3) Gouldner-professions in scientific and technical occupations and cultural specialists, and (4) Kristol-professionals in the arts, media, teaching and academic research, and government regulatory and welfare activities.
} 
Ehrenreich, John, and Barbara Ehrenreich. 1977. "The Professional-Managerial Class." Radical America 11:3-6.

Flanagan, Scott C. 1982. "Changing Values in Advanced Industrial Societies." Comparative Political Studies 14:403-44.

Giddens, Anthony. 1973. The Class Structure of Advanced Societies. New York: Harper.

Gouldner, Alvin W. 1979. The Future of Intellectuals and the Rise of the New Class. New York: Seabury.

Inglehart, Ronald. 1977. The Silent Revolution: Changing Values and Political Style among Western Publics. Princeton, N.J.: Princeton University Press.

Kristol, Irving. 1972. "About Inequality." Commentary 54:41-47.

Ladd, Everett C., Jr. 1978. The New Lines Are Drawn: Class and Ideology in America, Part 1." Public Opinion 3:48-53.

Lamont, Michele, and Annette Lareau. 1986. "Cultural Capital: A Critical Review." Paper presented at the annual meeting of the American Sociological Association, New York.

Lipset, Seymour Martin. 1981. Political Man. Rev. ed. updated. Baltimore: Johns Hopkins University Press.

Miller, S. Michael. 1975. "Notes on Neo-Capitalism." Theory and Society 2:1-36.

National Opinion Research Center (NORC). 1974-80. General Social Surveys. Chicago: NORC, University of Chicago.

Weber, Max. 1968. Economy and Society, vol. 1. New York: Westminster.

\section{CLASSIFICATION STRUGGLES: REPLY TO LAMONT}

I welcome Michele Lamont's comment on my paper. The issues she raises are important ones, and her arguments are plausible. However, I am not persuaded by her criticisms of the paper.

Her first argument is that my findings can be explained parsimoniously by emphasizing variations in professionals' "relative independence from profit maximization." She interprets my data as suggesting that "political liberalism among the new-class occupational categories varies inversely with the dependence of an individual's job on profit maximization and with the instrumentality of his knowledge for profit maximization." She goes on to argue that professionals who are not closely connected to profitmaximization activities may be properly considered to share a common "class situation."

The first part of this argument strikes me as a useful, if oversimplified, way of theorizing the relationships I found between political attitudes and occupational and sectoral categories. Why oversimplified? First, nonprofit workers involved in social control activities or in the defense of national interests (e.g., states' legal and military professionals) tend to be conservative, even though they are distant from "profit maximization." Second, intellectual occupations that may be closely tied to profit-making activities (e.g., writers, editors, and academic scientists) include a dispro- 